\title{
Population Dynamics of Wheat Root Pathogens Under Different Tillage Systems in Northeast Oregon
}

\author{
Chuntao Yin, ${ }^{1}$ Katherine McLaughlin, ${ }^{2}$ Timothy C. Paulitz, ${ }^{3}$ Duncan R. Kroese, ${ }^{4}$ and Christina H. Hagerty ${ }^{4, \dagger}$ \\ ${ }^{1}$ Department of Plant Pathology, Washington State University, Pullman, WA 99164-6430 \\ ${ }^{2}$ Department of Statistics, Oregon State University, Corvallis, OR 97331 \\ ${ }^{3}$ USDA-ARS, Wheat Health, Genetics and Quality Research Unit, Washington State University, Pullman, WA 99164-6430 \\ ${ }^{4}$ Columbia Basin Agricultural Research Center, Oregon State University, Adams, OR 97810
}

\begin{abstract}
No-till or direct seeding can be described as seeding directly into the crop stubble from the previous season without use of tillage. A reduction in tillage can result in many benefits, including increased soil organic matter, increased water holding capacity, and reduced fuel costs. However, the effect of no-till and reduced tillage on crop root disease profiles is poorly understood. To study the effect of tillage on disease dynamics, soil samples were collected from commercial wheat fields representing a wide range of tillage strategies in fall 2016 and fall 2017. Because precipitation might affect soilborne diseases, wheat fields located across a diverse gradient of precipitation zones of the dry-

plating showed that the colony counts of Fusarium, Pythium, and Rhizoctonia at the genus level were negatively associated with tillage. However, the same patterns were not observed when specific causal agents of Fusarium, Pythium, and Rhizoctonia that are known to be pathogenic on wheat were quantified with qPCR. Furthermore, precipitation affected the population density of some fungal pathogens $(F$. culmorum, $P$. ultimum, and $R$. solani AG 8). Within the scope of inference of this study, results of this study indicate that the benefits of adopting reduced tillage likely outweigh potential risk for increased root disease.
\end{abstract} land Pacific Northwest were selected. Fusarium spp., Pythium spp., and Rhizoctonia spp. were quantified from soil samples using soil dilution plating and quantitative PCR (qPCR) assays. Results of dilution
Keywords: field crops, cereals and grains, disease management, cultural and biological practices, pathogen diversity
Wheat (Triticum aestivum L.) is an important staple grain crop to feed a growing human population. In the inland Pacific Northwest (iPNW) of the United States, wheat is the predominant crop, accounting for approximately $17 \%$ of the national wheat production (USDA National Agriculture Statistics Service 2017). In the past 20 years, the iPNW has seen an increase of wheat producers adopting a notill or reduced tillage strategy. No-till acreage for all wheat in Oregon increased from $1 \%$ in 1996 to $17 \%$ in 2004 , and from 3 to $13 \%$ in Washington (Smiley et al. 2005b). No-till acreage continues to increase in the iPNW annually (Yorgey and Kruger 2017). Some dryland counties in Oregon, including Wasco and Gilliam, are currently estimated to be over $75 \%$ no-till (Sandy McNab, personal communication).

No-till or direct seeding can be described as seeding directly into the crop stubble from the previous season without use of tillage that disturbs soil. No-till strategies are highly diverse. Although no-till versus conventional tillage is often discussed as a qualitative scale, it is important to recognize the highly quantitative tillage scales and unique tillage strategies used by individual farms. Many farms may utilize a no-till drill for seeding and fertilizing, but they may also

${ }^{\dagger}$ Corresponding author: C. H. Hagerty; christina.hagerty@ oregonstate.edu

C. Yin and K. McLaughlin contributed equally and should be considered cofirst authors.

Funding: This research was made possible by funding from the Oregon Wheat Commission and the USDA-ARS.

*The $\boldsymbol{e}$-Xtra logo stands for "electronic extra" and indicates that three supplementary figures are published online.

The author(s) declare no conflict of interest.

Accepted for publication 10 April 2020.

(C) 2020 The American Phytopathological Society utilize vertical tillage implements, chisel plowing, field cultivating, or tandem disking to accomplish weed control and/or residue management at critical stages in the production cycle. Management strategies ranging between strict no-tillage and inversion tillage are generally referred to as conservation tillage or mulch tillage. Wheat yields in arid and rainfed conditions, such as in the dryland iPNW (Hagerty et al. 2019), are significantly improved in no-till conditions (Pittelkow et al. 2015).

Soilborne diseases caused by fungal pathogens are important constraints on wheat yield and grain quality (Dada 2017; Kazan and Gardiner 2018; Martin and Loper 1999). A shift in cultural management from conventional tillage to no-till or reduced tillage may present challenges with management of the root rot complex (Cook 2001; Paulitz 2006; Paulitz et al. 2002). The root rot complex, comprising Fusarium spp., Pythium spp., and Rhizoctonia spp., is a major contributor to wheat yield loss in the iPNW. Fusarium spp. can cause crown rot or foot rot of wheat. Fusarium pseudograminearum and $F$. culmorum are the predominant Fusarium species in the iPNW (Poole et al. 2013; Smiley and Patterson 1996; Smiley et al. 2005a). Infected wheat shows symptoms of chocolate to reddish-brown discoloration on roots and lower stem internodes. Genetic resistance to Fusarium crown rot is poorly understood (Smiley et al. 2005a). Pythium spp. cause root rot stunting and damping-off of wheat. Pythium root rot is prevalent in cool, wet soils, typical in direct-seeded wheat fields, and is one of the most widely distributed yield-limiting diseases of wheat in North America (Cook et al. 1980; Higginbotham et al. 2004; Paulitz et al. 2002). Among Pythium species, Pythium ultimum, $P$. irregulare, $P$. abappressorium, and $P$. rostratifingens were the most important species to wheat. Genetic resistance to Pythium is not available (Bockus et al. 2010). Rhizoctonia spp. cause rotting of wheat roots, damping-off of seedlings, stunting, and bare patches. According to the hyphal incompatibility, sequence variations, and host specificity, Rhizoctonia solani is classified into anastomosis groups (AGs) (Anderson 1982; González et al. 2006). R. solani AG 8 was most pathogenic to wheat (Roberts and Sivasithamparam 1986). Rhizoctonia root rot and bare patch caused by $R$. solani AG 8 can be severe in direct-seeded wheat (Cook et al. 2002; Paulitz et al. 
2002; Smiley et al. 1996). However, $R$. solani AG 2-1 is pathogenic to dicotyledonous crop species belonging to Brassicaceae, such as canola, and is weakly pathogenic to barley and wheat roots (Tewoldemedhin et al. 2006). Mazzola et al. (1996) and Paulitz et al. (2002) reported that more than $50 \%$ of the Rhizoctonia spp. isolated from iPNW wheat fields was $R$. oryzae, which caused damping-off and reduced root numbers of wheat, and suggested it might play an important role in wheat root disease. In contrast, Smiley and Uddin (1993) suggested that AG 8 was more important because they found $R$. oryzae did not cause root rots or limit yields of winter wheat. To date, no resistant commercial wheat cultivars are available to growers.

Environmental factors, such as temperature, moisture, soil type, nutrition, and geographical region, affect soilborne pathogens and the diseases they cause. Among them, temperature and moisture are the most important factors and are essential to the growth, survival, and distribution of many pathogens. In a conservation tillage system, increased surface soil moisture and cooler soil surface temperatures, particularly in springtime, may contribute to increased levels of root disease (Bockus and Shroyer 1998; Cook 2001). Wong et al. (1984) demonstrated that there was a significant interaction between temperature and moisture for $F$. avenaceum, $P$. irregulare, and $R$. solani or their combinations. Fusarium crown rot severity was negatively correlated with precipitation and was positively correlated with temperature (Smiley and Yan 2009). Damping-off pathogens are also favored in wet and cool soils (Lamichhane et al. 2017). Furthermore, larger stubble size and intact wheat crowns in conservation tillage systems take longer to break down than smaller substrate pieces that have been broken down with tillage (Smiley et al. 2012). Larger straw pieces with longer time to decay may increase available refugia for pathogenic fungi to complete the lifecycle and infect the following crop.

Tillage has varying effects on root diseases caused by soilborne fungal pathogens, with either increases or decreases in observed diseases (Bockus and Shroyer 1998; Larkin 2015). The effect of no-till or reduced tillage on root diseases of winter wheat is not fully understood. Therefore, additional research is needed to reveal how tillage influences disease dynamics. We hypothesized that the population density of three yield-limiting pathogens (Fusarium spp., Pythium spp., and Rhizoctonia spp.) in soil collected from commercial winter wheat fields would correlate with tillage intensity and annual precipitation zone in the iPNW. The objectives of this study were (i) to examine the relationship between tillage and the population density of Fusarium spp., Pythium spp., and Rhizoctonia spp. using conventional dilution plating and quantitative PCR (qPCR) assays; (ii) to determine how these fungal pathogens are distributed across a range of precipitation zones in Umatilla County, OR; and (iii) to investigate if crop tillage and annual precipitation influence the soilborne pathogens using statistical modeling.

\section{Materials and Methods}

Field locations. All wheat farms included in this study represented a wide range of tillage practices in Umatilla County, OR. Total farm acreage ranged from approximately 2,000 acres to 6,000 acres. Surveyed farms practice a winter wheat-summer fallow rotation typical of the region except for one field, which was unexpectedly planted to canola in 2017. Although crop rotation is a key cultural practice to limit soilborne disease, producers within the rainfall zone studied do not have the annual precipitation to support nonwheat crops. Upon sampling each of the 30 fields, photographs of the fields were taken to objectively identify the tillage strategy utilized by the grower. The photographs were organized from no tillage to complete inversion tillage by utilizing key features of tillage strategy: soil clod size and aggregation, and mulch/residue layer on the soil surface. This strategy resulted in a 10-point scale with like fields grouped in the same category, with normal distribution along the 10-point scale. In addition, annual precipitation data were obtained for each sampled field from Climate Engine for 2016 and 2017, respectively (Huntington et al. 2017). Fields surveyed ranged from 21.6 to $55.13 \mathrm{~cm}$ of annual precipitation.
Soil sampling. Soil was collected within 3 weeks in fall 2016 and fall 2017 using the same method. Briefly, samples were taken at least $30 \mathrm{~m}$ into the field to avoid edge effects. Ten soil cores per field of $30 \mathrm{~cm}$ depth by $2 \mathrm{~cm}$ diameter were taken every $60 \mathrm{~m}$ along a $610-\mathrm{m}$ transect utilizing a stainless-steel soil probe (JMC Soil Samplers, Newton, IA), and GPS coordinates were marked at each of the 10 sample locations along the transect. Cores were collected between rows for a bulk soil sample with minimal root matter (i.e., this was not a soil rhizosphere sample). For this study, only the 0 to $7.5-\mathrm{cm}$ depth was utilized and passed through a $2-\mathrm{mm}$ sieve in preparation for the pathogen quantification procedures. For 2016 samples, 10 cores were randomly divided into two groups of five and combined for dilution plating to result in two representative samples per field. For 2017 samples, the same fields were used, and five of the 10 cores were randomly selected and kept separate for qPCR analysis.

Soil dilution plating and baiting. In 2016, soil was analyzed by soil dilution plating and baiting procedures.

A modified clarified V8 agar selective medium was used to determine Pythium spp. populations in soil, which was amended with $10 \mathrm{mg} /$ liter of natamycin, $20 \mathrm{mg} /$ liter of rifampicin, $20 \mathrm{mg} / \mathrm{liter}$ of rose bengal, $250 \mathrm{mg} / \mathrm{liter}$ of ampicillin, and $120 \mathrm{mg} / \mathrm{liter}$ of pentachloronitrobenzene. For each sample, $10 \mathrm{~g}$ of soil was added to $90 \mathrm{ml}$ of $0.1 \%$ water agar and mixed thoroughly. Soil solution $(0.5 \mathrm{ml})$ was then pipetted onto a plate of the selective medium and was spread evenly across the surface using a glass cell spreader. Then the plates were cultured at room temperature for $36 \mathrm{~h}$. The total number of Pythium spp. colonies per plate was then counted. Each sample included four replicates.

A modified Komada's selective medium was used to determine Fusarium spp. populations in soil. Komada's selective medium was amended with $1 \mathrm{mg} /$ liter of benomyl and $1 \mathrm{~g} /$ liter of lithium chloride (Komada 1975). Two milliliters of the soil solution from the Pythium dilution plating procedure was added to $18 \mathrm{ml}$ of $0.1 \%$ water agar and mixed thoroughly. Soil solution $(0.5 \mathrm{ml})$ was then pipetted onto a plate of modified Komada's selective medium and was spread evenly across the surface using a glass cell spreader. The plates were cultured under constant light at room temperature for 1 week, at which point the total number of Fusarium spp. colonies per plate was counted. Each sample included four replicates.

To measure Rhizoctonia spp. populations in soil, $10 \mathrm{~g}$ of sieved soil was added to $1.5 \mathrm{ml}$ of double-distilled water $\left(\mathrm{ddH}_{2} \mathrm{O}\right)$ in a 15 $\mathrm{ml}$ plastic disposable test tube and mixed thoroughly. The cap of the tube was loosely screwed on, and the samples were cultured in the dark at room temperature for $24 \mathrm{~h}$. After incubation, four sterilized toothpicks were inserted to a depth of $5 \mathrm{~cm}$ into the soil. The cap of the tube was loosely screwed on, and the samples continued to incubate in the dark at room temperature for $48 \mathrm{~h}$. Then the toothpicks were removed from the soil using sterile forceps and placed onto plates of Rhizoctonia selective medium (20 g of agar/liter of deionized water, supplemented with $100 \mu \mathrm{g} / \mathrm{ml}$ of chloramphenicol and $1 \mu \mathrm{g} / \mathrm{ml}$ of benomyl), and Rhizoctonia spp. colonies were counted for each toothpick, as described by Paulitz and Schroeder (2005).

qPCR analysis. In order to create the DNA standard curves for qPCR, we used the root fungal pathogen cultures from the collection of T. Paulitz (USDA-ARS, Pullman), which included nine fungal pathogen isolates: Fusarium culmorum, F. pseudograminearum, Pythium ultimum, $P$. irregulare, $P$. abappressorium, $P$. rostratifingens, Rhizoctonia solani AG 8, $R$. solani AG2 1 , and $R$. oryzae. These fungi were grown in potato dextrose agar at room temperature. Mycelial mats were washed into centrifuge tubes with sterile $\mathrm{ddH}_{2} \mathrm{O}$ and centrifuged at maximum speed. The mycelial pellets were then utilized for DNA extraction. Fungal DNA was extracted using the FastDNA Kit (Qbiogene, Carlsbad, CA) according to the manufacturer's instructions and a FastPrep bead beater (MP Biomedical, Santa Ana, CA) using the fungal program.

qPCR primers for $F$. culmorum and $F$. pseudograminearum were designed from the translation elongation factor 1- $\alpha$ gene (TEF1- $\alpha$ ). The TEF1- $\alpha$ sequence of the other Fusarium spp. was retrieved from GenBank and aligned using ClustalW. Species-specific primers were 
designed with a minimum formation of secondary structure and an amplicon size of 100 to $200 \mathrm{bp}$, as well as using BLAST analysis to avoid cross reactions with other Fusarium spp. and fungi (Table 1). qPCR primers for $P$. rostratifingens were designed from the variable regions of ITS1 and ITS2 using similar criteria as Fusarium spp. qPCR primers for Pythium spp. and Rhizoctonia spp. were previously designed by Schroeder et al. (2006, personal communication) and Okubara et al. (2005) (Table 1).

The abundance of fungal pathogens from the 2017 samples was analyzed with qPCR assays. Five cores were randomly chosen, and DNA was extracted from individual cores and treated as individual observations. Soil ( $0.5 \mathrm{~g})$ was extracted using the MoBio PowerSoil kit (MoBio/Qiagen, Carlsbad, CA) according to the manufacturer's instructions and a FastPrep bead beater (MP Biomedical) using the soil program. DNA concentrations were measured using a NanoDrop 1000 spectrophotometer (Thermo Scientific, Waltham, MA).

qPCR was performed in a total volume of $10 \mu \mathrm{l}$ using KAPA SYBR FAST qPCR Master Mix kit I (Roche Applied Science, Indianapolis, IN) on a Roche LightCycler (Roche Applied Science). Each 10- $\mu$ l PCR reaction consisted of $5 \mu l$ of KAPA SYBR FAST qPCR Master Mix, 2 pmol of each primer, $4.6 \mu \mathrm{l}$ of fungal DNA or $2 \mu \mathrm{l}$ of soil DNA (concentration was diluted to $2 \mathrm{ng} / \mu \mathrm{l}$ ), and $\mathrm{ddH}_{2} \mathrm{O}$ to $10 \mu \mathrm{l}$. A standard curve was generated for each pair of primers, using nine fungal pathogen DNAs as a template, respectively. The DNA concentrations for each fungal pathogen were series diluted with 10 -fold reductions (DNA concentrations from 4 to $8 \mathrm{ng} / \mu \mathrm{l}$ to 0.4 to $0.8 \mathrm{pg}$ / $\mu \mathrm{l})$. The PCR program used was $95^{\circ} \mathrm{C}$ for $3 \mathrm{~min}$, followed by $45 \mathrm{cy}-$ cles of $95^{\circ} \mathrm{C}$ for $10 \mathrm{~s}, 60^{\circ} \mathrm{C}$ for $20 \mathrm{~s}$, and $72^{\circ} \mathrm{C}$ for $1 \mathrm{~s}$. To evaluate amplification specificity, melt curve analysis was generated followed by each PCR run. A melt curve profile was obtained by heating the mixture to $95^{\circ} \mathrm{C}$ for $5 \mathrm{~s}$, cooling to $65^{\circ} \mathrm{C}$ for $1 \mathrm{~min}$, and then incremental increases of 5 to $10^{\circ} \mathrm{C}$ up to $97^{\circ} \mathrm{C}$ with continuous measurement of fluorescence. All samples were amplified in triplicate. Each DNA concentration of fungal pathogens was calculated based on standard curves and expressed as picogram per nanogram of soil DNA.

Statistical analysis. The 2016 soil dilution plating and baiting resulted in a count of colonies for each of three fungal and fungallike pathogens per sample, with two samples per field. A generalized linear mixed-effects model with the Poisson link function to account for the count response was fit for each fungal pathogen using the "glmer" function in the "lme4" package in R (Bates et al. 2014). Field was treated as a random effect. Fixed effects considered were precipitation, tillage, seeded or fallow, and all interactions between effects. Model selection was conducted independently for each pathogen response variable. Fixed effects to include in the final model were selected with likelihood ratio tests using backward selection.
The 2017 qPCR analysis resulted in an abundance measurement expressed as a concentration for each of nine fungal pathogens per biological replicate, with five biological replicates per field. A linear mixed-effects model was fit for each fungal pathogen using the "Imer" function in the "Ime4" package in R (Bates et al. 2014). Field was treated as a random effect. Fixed effects considered were precipitation and tillage, as well as the interaction between tillage and precipitation. Model selection was conducted independently for each pathogen response variable. Fixed effects to include in the final model were selected with likelihood ratio tests using backward selection.

\section{Results}

Quantification of fungal pathogens in 2016 field samples using dilution plating assay. Fusarium, Pythium, and Rhizoctonia in the soil samples from 30 fields across four rainfall zones of Umatilla County, OR (Fig. 1) were detected and quantified using the dilution plating assay. Of the three most prevalent soil fungal and fungal-like pathogens, Fusarium spp. colony counts averaged across four technical replicates in all samples ranged from 0 to $6,850 \mathrm{CFU} / \mathrm{g}$ of soil. Reduced Fusarium spp. colony count occurred in fields with increased tillage in $2016(P=0.03)$ (Fig. 2A; Table 2$)$. There was no effect of the precipitation in 2016 on Fusarium spp. colony counts $(P=0.895)$ (Fig. 2B; Table 2), but it improved the Poisson generalized linear mixed model (GLMM) (Table 2).

Pythium spp. colony counts averaged across four technical replicates in all samples ranged from 0 to $35 \mathrm{CFU} / \mathrm{g}$ of soil. Similarly,

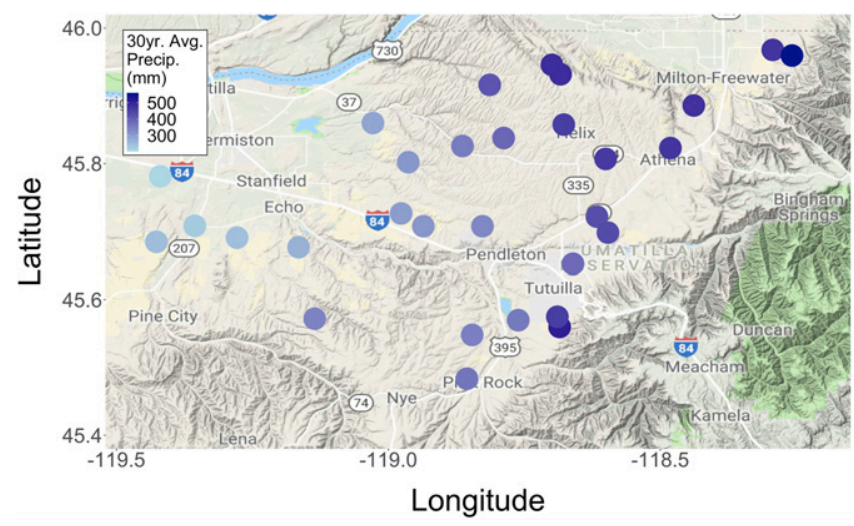

Fig. 1. Map of surveyed region of Umatilla County, OR. Each of 30 points represent a surveyed field. Shade of the point refers to precipitation zone of the surveyed field.

Table 1. Species-specific primers of fungal pathogens for qPCR assays

\begin{tabular}{|c|c|c|c|}
\hline Species & Primer & Sequence $\left(5^{\prime} \rightarrow 3^{\prime}\right)$ & Product size (bp) \\
\hline \multirow[t]{2}{*}{ Pythium ultimum } & ULT1F & GACACTGGAACGGGAGTCAGC & 414 \\
\hline & ULT4R & AAAGGACTCGACAGATTCTCGATC & \\
\hline \multirow[t]{2}{*}{ P. irregulare group IV } & IIV7F & GTATCGTCTTGGCGGAGTGG & 370 \\
\hline & ABA1R & TGCATAAACGAATATACCAACCGC & \\
\hline \multirow[t]{2}{*}{ P. abappressorium } & ABA1bF & GTTGTTGTGCGTCTGCGGATTTG & 397 \\
\hline & ABA1R & TGCATAAACGAATATACCAACCGC & \\
\hline \multirow[t]{2}{*}{ P. rostratifingens } & PROSF2 & GCGCAGATAGAGAGACTGATTTGG & 100 \\
\hline & PROSR2 & ACTACCAACACACACACACACACG & \\
\hline \multirow[t]{2}{*}{ Fusarium culmorum } & FCKY648945F & AGTACCACTGCATCCCAACC & 120 \\
\hline & FCKY648945R & CTTCTCGATGGTTCGCTTGT & \\
\hline \multirow[t]{2}{*}{ F. pseudograminearum } & FPKY927890F & GTGTCAATCAGTCACTAACAACC & 194 \\
\hline & FPKY927890R & GAGGACAATAGTGACAACATACC & \\
\hline \multirow[t]{2}{*}{ Rhizoctonia oryzae genotype III } & RoGr3F & CTGTTGAAACCGGTTTACTATG & 286 \\
\hline & RoGr3R & CTTCCAAGTCCAAATACAACAATC & \\
\hline \multirow[t]{2}{*}{ R. solani AG 8} & Rs8F & GGGGGAATTTATTCATTTATTGGAC & 327 \\
\hline & Rs8R & GGTGTGAAGCTGCAAAAG & \\
\hline \multirow[t]{2}{*}{ R. solani AG 2-1 } & AG 2-1F & GTTGTAGCTGGCCCATTCATTTG & 123 \\
\hline & AG 2-1R & CCTATTGCCTTTGTATTCCAAAAAGC & \\
\hline
\end{tabular}


Pythium spp. colony number significantly reduced with increased tillage in $2016(P=0.0009)$ (Fig. 3A; Table 2). The precipitation in 2016 slightly affected Fusarium spp. colony number $(P=$ 0.057 ) (Fig. 3B; Table 2). Seeded versus fallow did not have an impact on Pythium spp. colonies $(P=0.32)$ but improved the Poisson GLMM (Table 2).

Rhizoctonia spp. colony counts averaged across four technical replicates in all samples ranged from 0 to $6.9 \mathrm{CFU} / \mathrm{g}$ of soil. Interestingly, both tillage and precipitation in 2016 significantly affected Rhizoctonia colony counts. Rhizoctonia colony counts were reduced significantly with increased tillage $(P=0.002)$ (Fig. 4A; Table 2$)$ but increased with increased precipitation $(P=0.01)$ (Fig. 4B; Table 2).
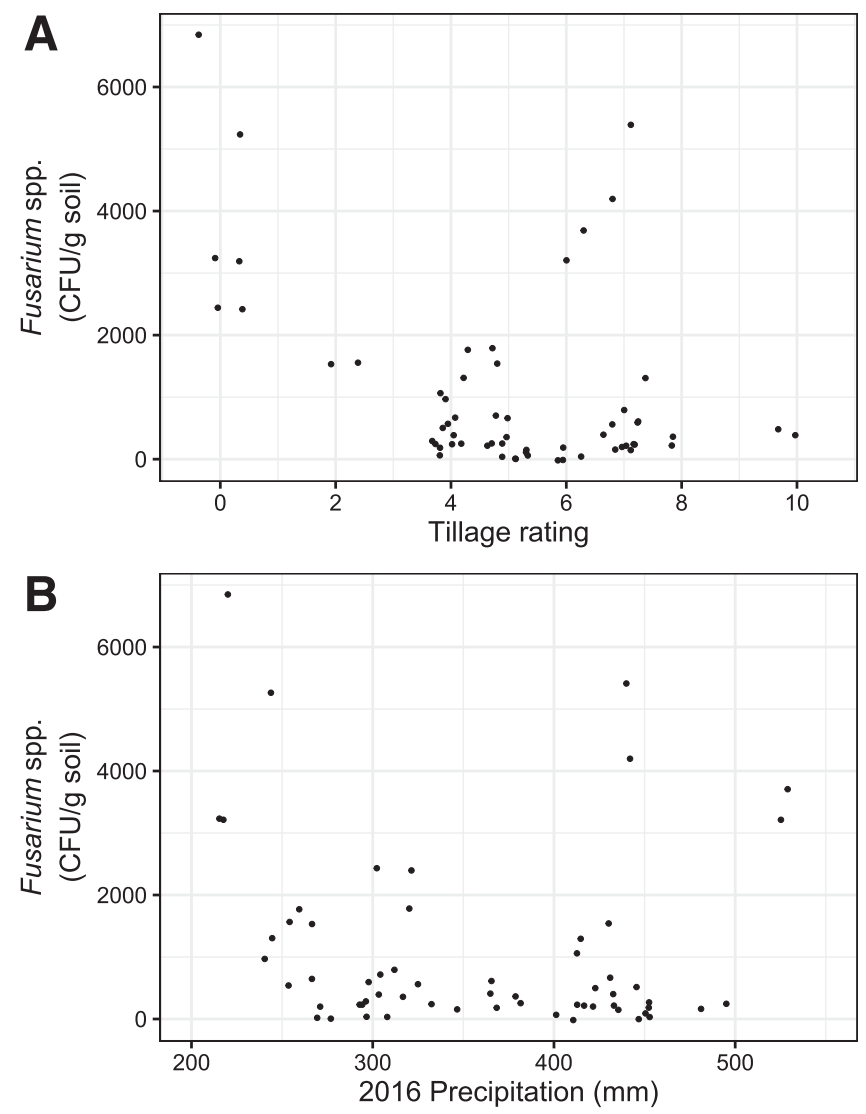

Fig. 2. Scatter plots of dilution plating quantification of Fusarium spp. colony forming units (CFU) per gram of soil collected from commercial winter wheat fields in Umatilla County, OR, under different tillage and precipitation regimes. A, Tillage scale: $0=$ no tillage, and $10=$ conventional inversion tillage. B, Different precipitation. Each point represents one technical replicate.

Table 2. Summary of best fit generalized linear mixed model for colony counts of fungal pathogens of commercial winter wheat fields under different environments in $2016^{\mathrm{a}}$

\begin{tabular}{llccl}
\hline Fungal pathogens & \multicolumn{1}{c}{ Fixed effects } & Coefficient & SE & P value \\
\hline Fusarium spp. & Intercept & 1.960 & 0.956 & $0.040^{*}$ \\
& Precipitation & 0.0004 & 0.003 & 0.895 \\
& Tillage & -0.246 & 0.114 & $0.030^{*}$ \\
Pythium spp. & Intercept & -2.154 & 1.678 & 0.199 \\
& Precipitation & 0.010 & 0.005 & 0.057 \\
& Tillage & -0.691 & 0.208 & $0.0009 * * *$ \\
& Seeded versus fallow & -0.950 & 0.948 & 0.316 \\
Rhizoctonia spp. & Intercept & 0.033 & 0.672 & 0.961 \\
& Precipitation & 0.006 & 0.002 & $0.010^{*}$ \\
& Tillage & -0.248 & 0.082 & $0.002^{* *}$ \\
\hline
\end{tabular}

${ }^{\mathrm{a}} \mathrm{SE}=$ standard error. Significance levels: $* * *=0 ; * *=0.001$; and $*=0.01$.
Quantification of fungal pathogens to species level in 2017 field samples using qPCR assay. qPCR was used to quantify fungal pathogens in the 2017 soil from 30 fields in the same locations. Specific primers were designed to identify and quantify fungal pathogens to species level. F. culmorum was detected in $99 \%$ of 150 soil samples at DNA concentrations ranging from $0.055 \pm 0.033$ to $16.804 \pm 1.905$ pg of DNA/ng of soil DNA. DNA quantity of $F$. culmorum in the soil was slightly affected by tillage $(P=0.051)$ but reduced dramatically with increased precipitation $(P=0.0007)$ (Fig. 5; Table 3). For $F$. pseudograminearum, the qPCR assay showed that $83 \%$ of 150 samples had detectable DNA at concentrations ranging from $0.030 \pm$ 0.000 to $43.261 \pm 5.487 \mathrm{pg}$ of DNA/ng of soil DNA. However, all fixed effects tested, including tillage and precipitation, did not have an impact on DNA quantity of $F$. pseudograminearum (Fig. 6; Table 3).

The four most prevalent pathogenic Pythium spp., including $P$. ultimum, $P$. irregulare, $P$. abappressorium, and $P$. rostratifingens, were analyzed. More than $96 \%$ of 150 samples had detectable amounts of all four Pythium spp., and DNA concentrations for $P$. ultimum, $P$. irregulare, $P$. abappressorium, and $P$. rostratifingens ranged from $0.007 \pm 0.000$ to $5.574 \pm 0.280 \mathrm{pg}$ of DNA/ng of soil DNA, from $0.035 \pm 0.003$ to $1.422 \pm 0.068 \mathrm{pg}$ of DNA/ng of soil DNA, from $0.0004 \pm 0.000$ to $7.104 \pm 0.678 \mathrm{pg}$ of DNA/ng of soil DNA, and from $0.012 \pm 0.001$ to $0.095 \pm 0.000 \mathrm{pg}$ of DNA/ng of soil DNA, respectively. Interestingly, DNA quantities of three Pythium spp. ( $P$. ultimum, $P$. irregulare, and $P$. abappressorium) in the soil were significantly reduced with increased tillage, and their $P$ values were $0.026,0.004$, and 0.004, respectively (Figs. 7A, 8A, and 9A; Table 3). Moreover, DNA quantity of $P$. ultimum in the soil was dramatically reduced with increased precipitation $(P=0.024)$. A similar pattern of precipitation impact on $P$. irregulare and $P$.
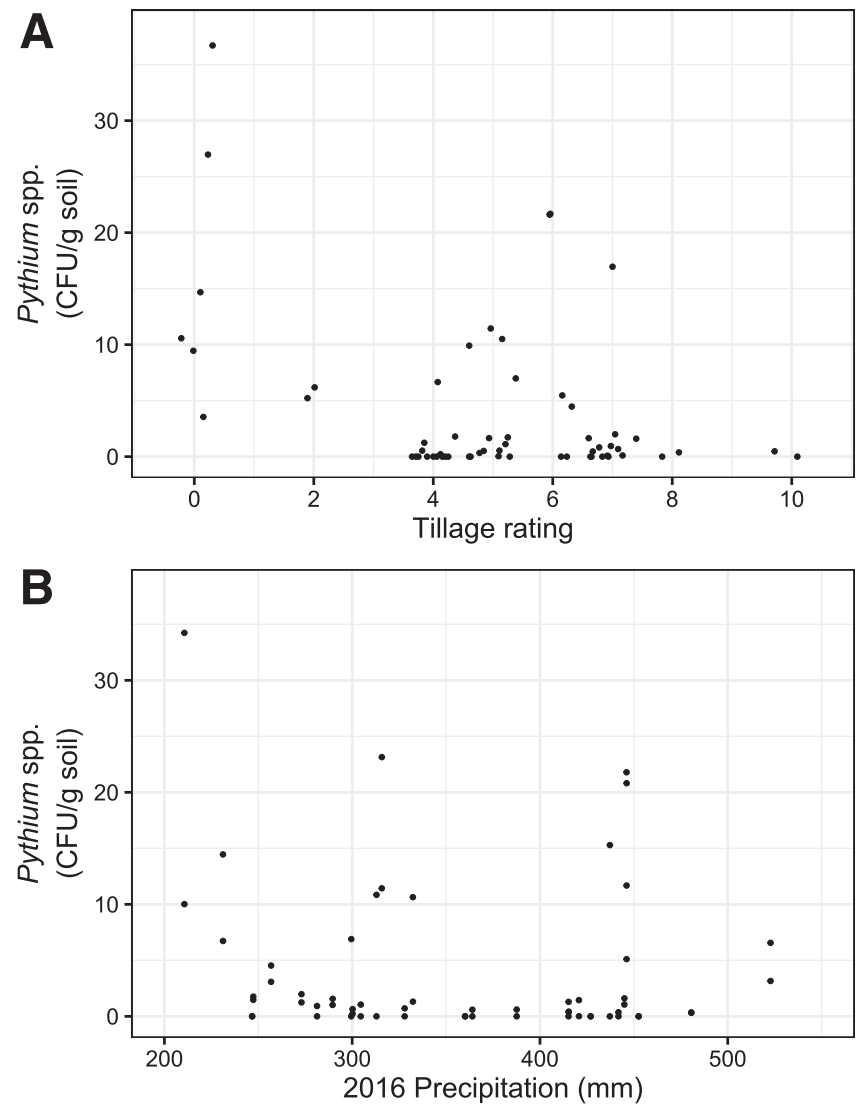

Fig. 3. Scatter plots of dilution plating quantification of Pythium spp. colony forming units (CFU) per gram of soil collected from commercial winter wheat fields in Umatilla County, OR, under different tillage and precipitation regimes. A, Tillage scale: $0=$ no tillage, and $10=$ conventional inversion tillage. B, Different precipitation. Each point represents one technical replicate. 
abappressorium was not observed (Fig. 8B and 9B; Table 3). However, no significant association was found between the fixed effects tested and DNA quantity of $P$. rostratifingens (Supplementary Fig. 1; Table 3).

Three pathogenic Rhizoctonia spp., including $R$. solani AG 8, $R$. solani AG 2-1, and $R$. oryzae, were quantified in the 2017 soil samples with qPCR assay. Only precipitation had an impact on $R$. solani AG 8 , and DNA quantity of AG 8 in the soil was negatively associated with precipitation $(P=0.03)$ (Fig. 10A; Table 3). The other fixed effects tested did not have an impact on DNA quantity of three Rhizoctonia spp. (Fig. 10B; Supplementary Figs. 2A and B, 3A and B; Table 3).

\section{Discussion}

Identification and quantitation of fungal pathogens in commercial wheat field soil is essential for disease control and to implement disease management strategies. In this study, prevalent soilborne fungal pathogens in soil collected from commercial winter wheat fields differing by tillage intensity and annual precipitation zone in the dryland Pacific Northwest were detected and quantified using dilution plating or qPCR assays in a continuous 2 years. Our study revealed higher colony counts of Fusarium, Pythium, and Rhizoctonia at the genus level with reduced tillage. However, the same patterns were not observed when specific causal agents of Fusarium, Pythium, and Rhizoctonia that are known to be pathogenic on wheat were quantified with qPCR. There were three pathogenic Pythium species ( $P$. ultimum, $P$. irregulare, and $P$. abappressorium) that followed a similar trend as the dilution plating results and were negatively associated with tillage. Precipitation was found to affect some fungal pathogen abundance, such as F. culmorum, P. ultimum, and R. solani AG 8. Within the scope of inference of this study, our findings suggest that the increase of root disease should not necessarily prevent producers from adopting a no-till strategy.

Soilborne fungal pathogens infect wheat and usually cause very similar symptoms, such as root rot, crown rot, stunting, seedling damping-off, and wilt. It is common that multiple species complexes exist in natural environments (Cook 2010; Moya-Elizondo 2013), which creates a challenge for disease diagnosis and detection. The combination of a conventional method and a molecular-based method, such as dilution plating and qPCR, can provide quantitative data of soilborne pathogens in farm soil, although the threshold of copy numbers and DNA concentrations of the different pathogens in wheat fields to cause disease is unknown. In this study, we employed a dilution plating assay for 2016 soil samples and a qPCR assay for 2017 samples. Two consecutive years of results did not show the same pattern except for three Pythium spp. The discrepancy might also be explained by the fact that dilution plating might detect the culturable species including pathogenic and nonpathogenic species but overlook those at low population density or slowly growing species. In contrast, the qPCR assay is very sensitive and capable of detecting specific species, nonculturables, and low densities of fungal pathogens (Okubara et al. 2008; Schroeder et al. 2006; Woodhall et al. 2013). Another reason for the discrepancy could be that the selective media used in dilution plating (Mihail and Singleton 1992) are designed to reduce other fungi contamination but do not eliminate them completely. In addition, fungi may exist in soil with different development stages; for example, Rhizoctonia produces dormant sclerotia that are in too low a population to be detectable. Moreover, the population dynamics of these fungal pathogens is very complex; for example, more than 10 Pythium species and dozens of Fusarium species cause root rot in wheat and barley (Chamswarng and Cook 1985; Dweba et al. 2017; Higginbotham et al. 2004; Schroeder
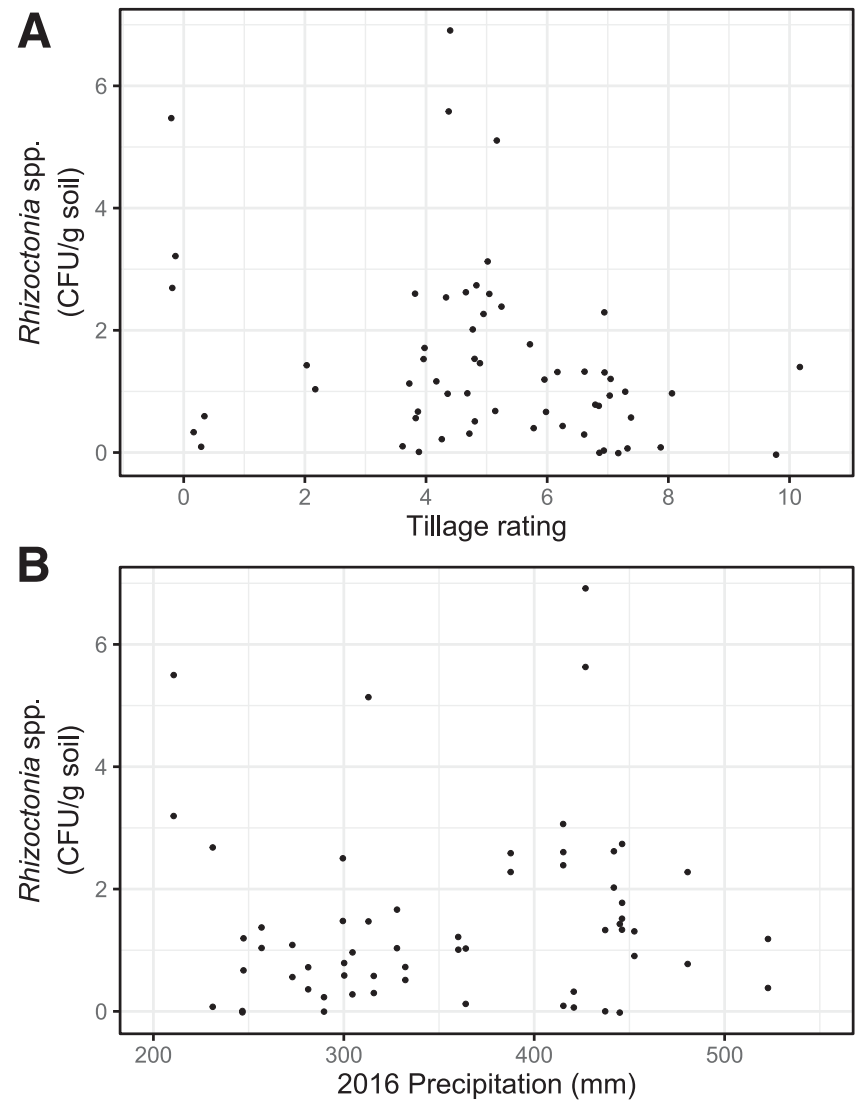

Fig. 4. Scatter plots of soil baiting quantification of Rhizoctonia spp. colony forming units (CFU) per gram of soil collected from commercial winter wheat fields in Umatilla County, OR, under different tillage and precipitation regimes. A, Tillage scale: $0=$ no tillage, and $10=$ conventional inversion tillage. B, Different precipitation. Each point represents one technical replicate.
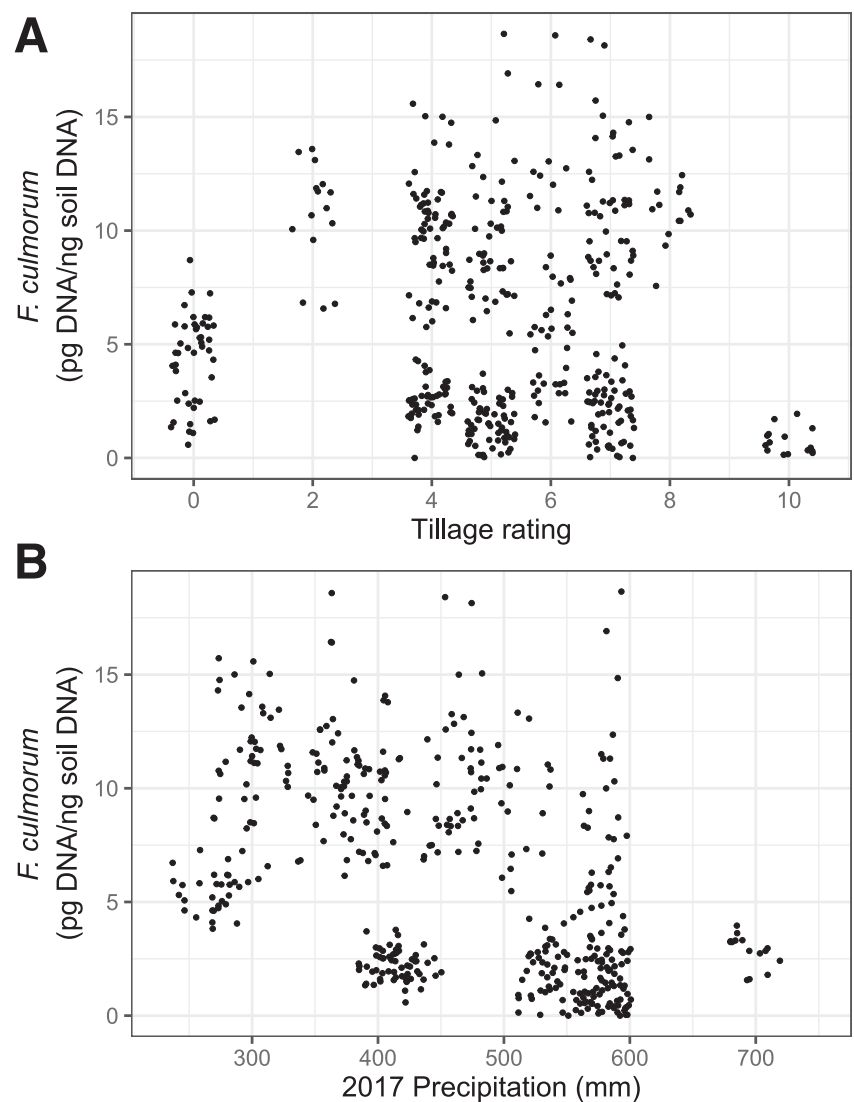

Fig. 5. Scatter plots of qPCR quantification of Fusarium culmorum $\mathrm{pg}$ of DNA/ng of soil DNA collected from commercial winter wheat fields in Umatilla County, OR, under different tillage and precipitation regimes. A, Tillage scale: $0=$ no tillage, and $10=$ conventional inversion tillage. B, Different precipitation. Each point represents one technical replicate. 
et al. 2006). Out of this complex, only nine predominant species of Fusarium, Pythium, and Rhizoctonia that are pathogenic to wheat were analyzed with qPCR.

Fusarium can produce notoriously variable symptoms in the field (Smiley and Yan 2009) and has a stubble-borne portion of the lifecycle (Bockus et al. 2010). Tillage is often considered as a good practice to reduce the risk of Fusarium disease development in cereals (Hofgaard et al. 2016; Munger et al. 2014; Steinkellner and Langer
2004). However, it is sometimes difficult to find a direct link between tillage and Fusarium disease development (Lori et al. 2009; Maiorano et al. 2008). In our study, elevated levels of all Fusarium in our 2016 dilution plating effort were observed, whereas qPCR on 2017 samples indicated specific causal agents in our region, including $F$. culmorum and $F$. pseudograminearum, are not highly influenced by tillage. Statistical modeling efforts in this study show that $F$. culmorum is influenced by tillage, but we cannot conclude the

Table 3. Summary of linear mixed models for DNA quantity of fungal pathogens of commercial winter wheat fields under different environments in $2017^{\mathrm{a}}$

\begin{tabular}{|c|c|c|c|c|c|}
\hline \multicolumn{2}{|c|}{ Fungal pathogens } & \multirow{2}{*}{$\begin{array}{l}\text { Fixed effects } \\
\text { Intercept }\end{array}$} & \multirow{2}{*}{$\begin{array}{c}\text { Coefficient } \\
14.702\end{array}$} & \multirow{2}{*}{$\frac{\mathrm{SE}}{2.707}$} & \multirow{2}{*}{$\frac{P \text { value }}{9.59 \mathrm{e}-06 * * *}$} \\
\hline Fusarium spp. & F. culmorum & & & & \\
\hline & & Precipitation & -0.0260 & 0.007 & $0.0007^{* * *}$ \\
\hline & & Tillage & 0.693 & 0.338 & 0.051 \\
\hline & F. pseudograminearum & Intercept & 2.231 & 0.431 & $1.45 \mathrm{e}-05^{* * *}$ \\
\hline \multirow[t]{8}{*}{ Pythium spp. } & P. ultimum & Intercept & 1.752 & 0.307 & $4.52 \mathrm{e}-06^{* * *}$ \\
\hline & & Precipitation & -0.002 & 0.001 & $0.024 *$ \\
\hline & & Tillage & -0.090 & 0.038 & $0.026^{*}$ \\
\hline & P. irregulare & Intercept & 0.808 & 0.105 & $2.2 \mathrm{e}-08 * * *$ \\
\hline & & Tillage & -0.059 & 0.019 & $0.004 * *$ \\
\hline & P. abappressorium & Intercept & 1.905 & 0.329 & $3.19 \mathrm{e}-06 * * *$ \\
\hline & & Tillage & -0.186 & 0.060 & $0.004 * *$ \\
\hline & P. rostratifingens & Intercept & 0.048 & 0.002 & $<2 \mathrm{e}-16^{* * *}$ \\
\hline \multirow[t]{4}{*}{ Rhizoctonia spp. } & R. solani AG 8 & Intercept & 4.287 & 1.451 & $0.0036^{* *}$ \\
\hline & & Precipitation & -0.006 & 0.003 & $0.038 *$ \\
\hline & R. solani AG 2-1 & Intercept & 0.129 & 0.032 & $0.0003 * * *$ \\
\hline & R. oryzae & Intercept & 0.396 & 0.274 & 0.159 \\
\hline
\end{tabular}

${ }^{\text {a }} \mathrm{SE}=$ standard error. Significance levels: $* * *=0 ; * *=0.001$; and $*=0.01$.
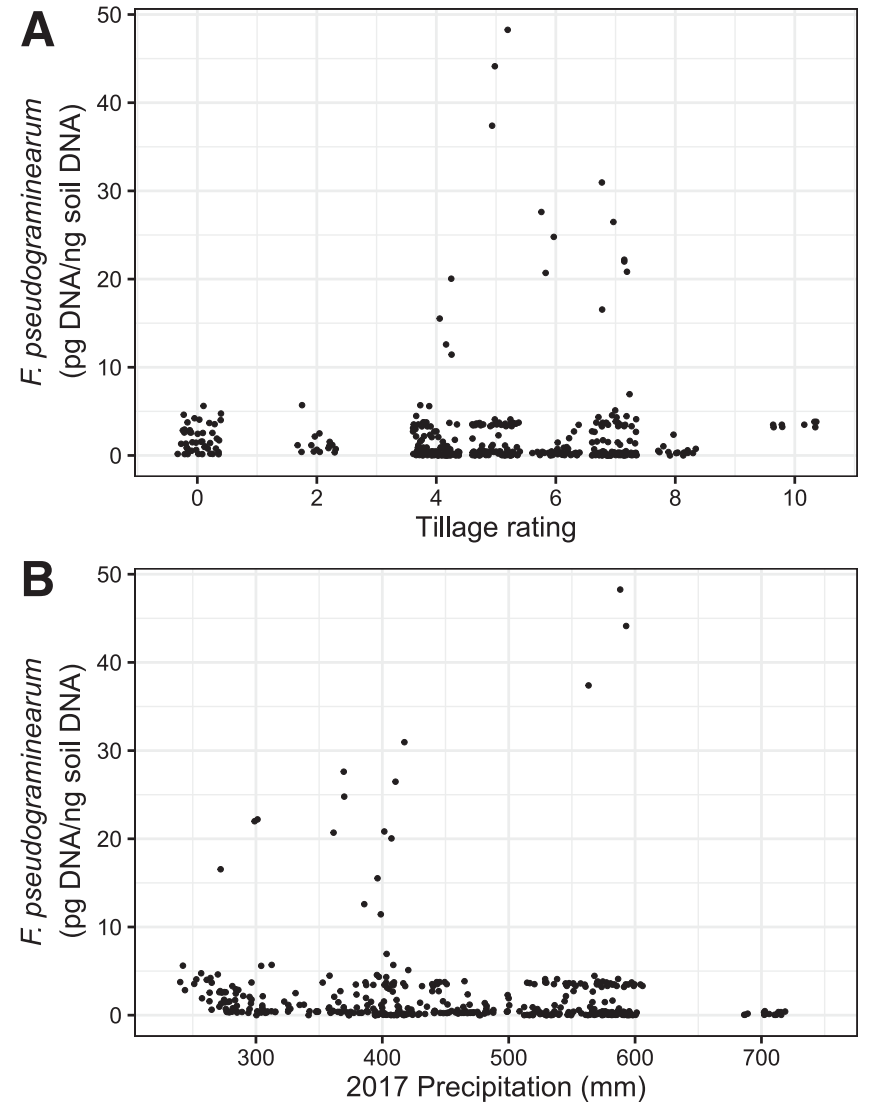

Fig. 6. Scatter plots of qPCR quantification of Fusarium pseudograminearum pg of DNA/ng of soil DNA collected from commercial winter wheat fields in Umatilla County, OR, under different tillage and precipitation regimes. A, Tillage scale: $0=$ no tillage, and $10=$ conventional inversion tillage. B, Different precipitation. Each point represents one technical replicate.
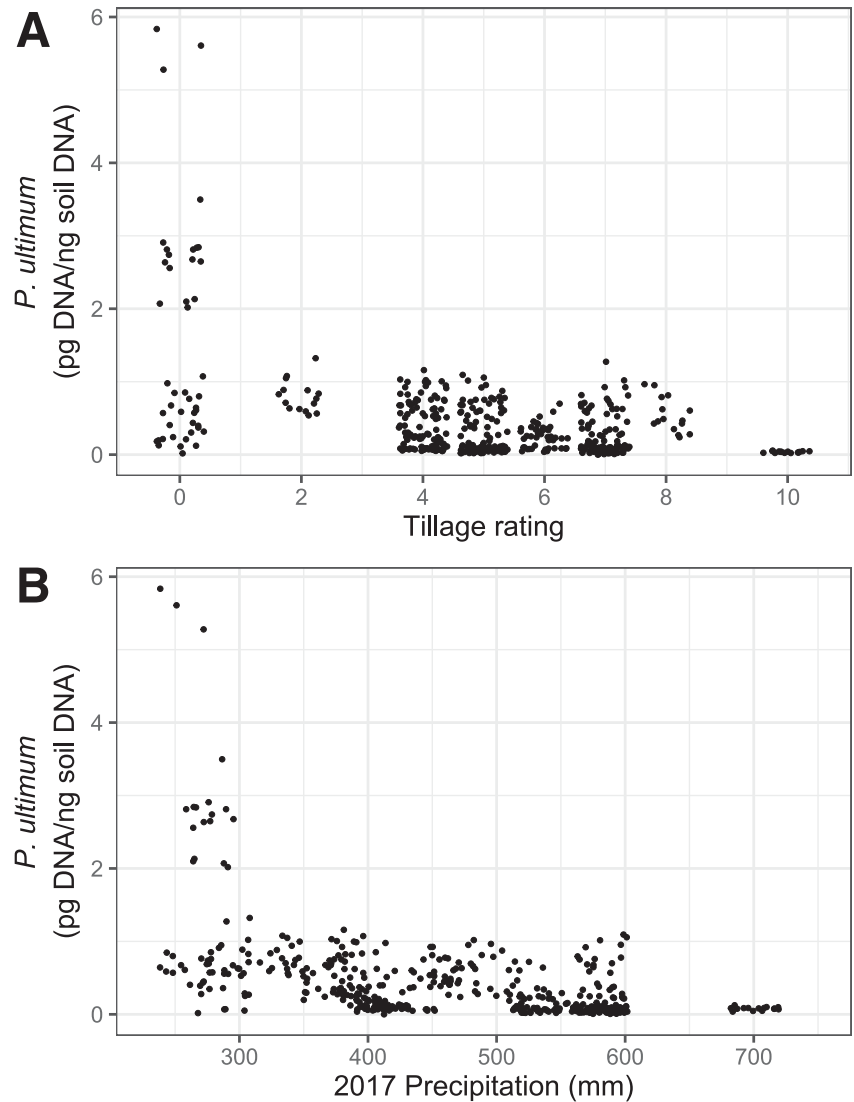

Fig. 7. Scatter plots of qPCR quantification of Pythium ultimum pg of DNA/ng of soil DNA collected from commercial winter wheat fields in Umatilla County, OR, under different tillage and precipitation regimes. A, Tillage scale: $0=$ no tillage, and $10=$ conventional inversion tillage. B, Different precipitation. Each point represents one technical replicate. 
directionality of the response. F. pseudograminearum was not influenced by tillage or any of the fixed effects measured in this study. Additionally, highly replicated studies are needed to overcome the inherent in-field variability associated with the causal agents of Fusarium crown rot (Smiley and Yan 2009) to understand drivers of variability and make practical conclusions for wheat producers. Studies have shown that Fusarium crown rot incidence was significantly higher in systems with high stubble retention (Wildermuth et al. 1997). However, the opposite has also been shown; several studies have found less root rot disease under no-tillage compared with conventional tillage (De Boer and Kollmorgen 1988; Salas and Stack 1988; Tinline and Spurr 1991). Other studies show a neutral effect of tillage on soilborne plant pathogens (Conner et al. 1987; Lawn and Sayre 1989; Windels and Wiersma 1989).

Of the soilborne pathogens we assessed, Pythium was most highly influenced by tillage in this study. This result could be due, in part, to tillage physically disrupting aspects the Pythium life cycle, including germination of the oospore, formation of the zoosporangium, and/or vesiculation of the sporangium. However, the most likely driver of higher Pythium spp. in reduced tillage systems is the cooler and wetter soil environment in reduced tillage systems that function to promote Pythium infection. Pythium infection of winter wheat has been shown to be greatest in cool, wet, high-residue seed beds, which essentially define reduced or no-tillage conditions (Bockus and Shroyer 1998; Cook 2001; Cook et al. 1980; Ingram and Cook 1990). Limited studies support our result of increased Pythium in no-tillage systems of winter wheat (Cook et al. 1980; Pankhurst et al. 1995).

Rhizoctonia is arguably the most studied pathogen in regard to tillage. Life cycle features of mycelial growth in soil can be disrupted by tillage and may have the capacity to reduce disease. Tillage may also
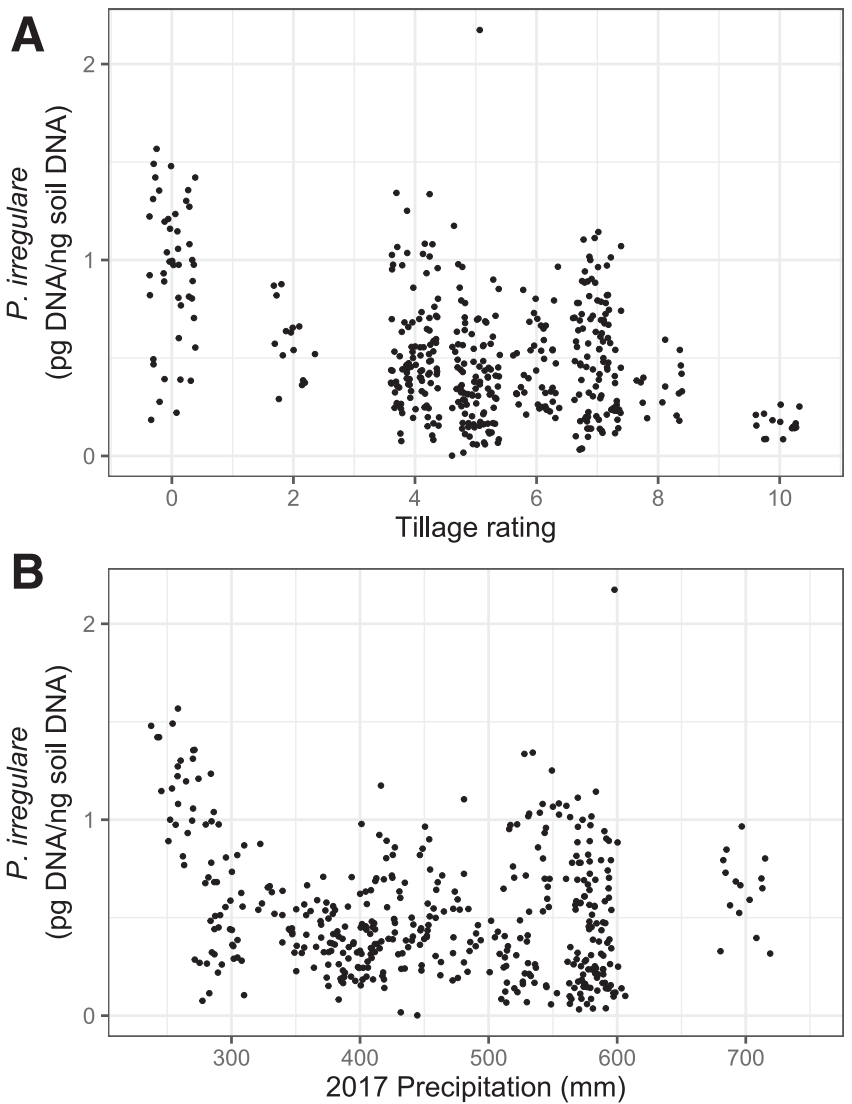

Fig. 8. Scatter plots of qPCR quantification of Pythium irregulare pg of DNA/ng of soil DNA collected from commercial winter wheat fields in Umatilla County, OR, under different tillage and precipitation regimes. A, Tillage scale: $0=$ no tillage, and $10=$ conventional inversion tillage. B, Different precipitation. Each point represents one technical replicate. change microbial activity in the soil to suppress Rhizoctonia (Paulitz 2006; Yin et al. 2017). We found $R$. solani AG 8 in the 2017 soil was negatively associated with precipitation, which supports the observation in dryland wheat production zones of Washington State (Okubara et al. 2014). However, we did not see trends of increased Rhizoctonia in reduced tillage environments, because tillage did not improve the model fit for $R$. solani AG $8, R$. solani AG 2-1, or $R$. oryzae. Our result is in disagreement with several studies that have shown soil cultivation reduces Rhizoctonia. The literature on tillage effects with $R$. solani is abundant, especially from Australia, where researchers have documented that disease severity is significantly less in cultivated compared with direct-seeded treatments (MacNish 1985; Pumphrey et al. 1987; Roget 1995; Rovira 1986). R. oryzae may not be impacted by tillage as much as $R$. solani, because it infects from microsclerotia that are likely resistant to tillage disturbance (Anderson 1982; Okubara et al. 2014). In addition, cooler, wetter environmental conditions in no-till systems may favor $R$. solani. Greenhouse-based studies have shown that $R$. solani AG 8 causes more severe root rot at low temperatures than at high temperatures, but $R$. oryzae was less influenced by temperature (Smiley and Uddin 1993).

Reduced tillage was invented in the 1960s but did not gain adoption until the 1990s. Since its invention, no-till acreage has steadily increased worldwide; however, uncertainty related to pathogen shifts in no-till management has slowed the adoption of no-till farming globally. A likely cause of the conflicting evidence in the literature regarding pathogen dynamics in no-till systems is the duration of time the field has been managed without tillage. Abiotic benefits of conservation tillage, including increased organic matter, reduced erosion, and increased water infiltration, can take time to be realized by the farmer. Similarly, it may take
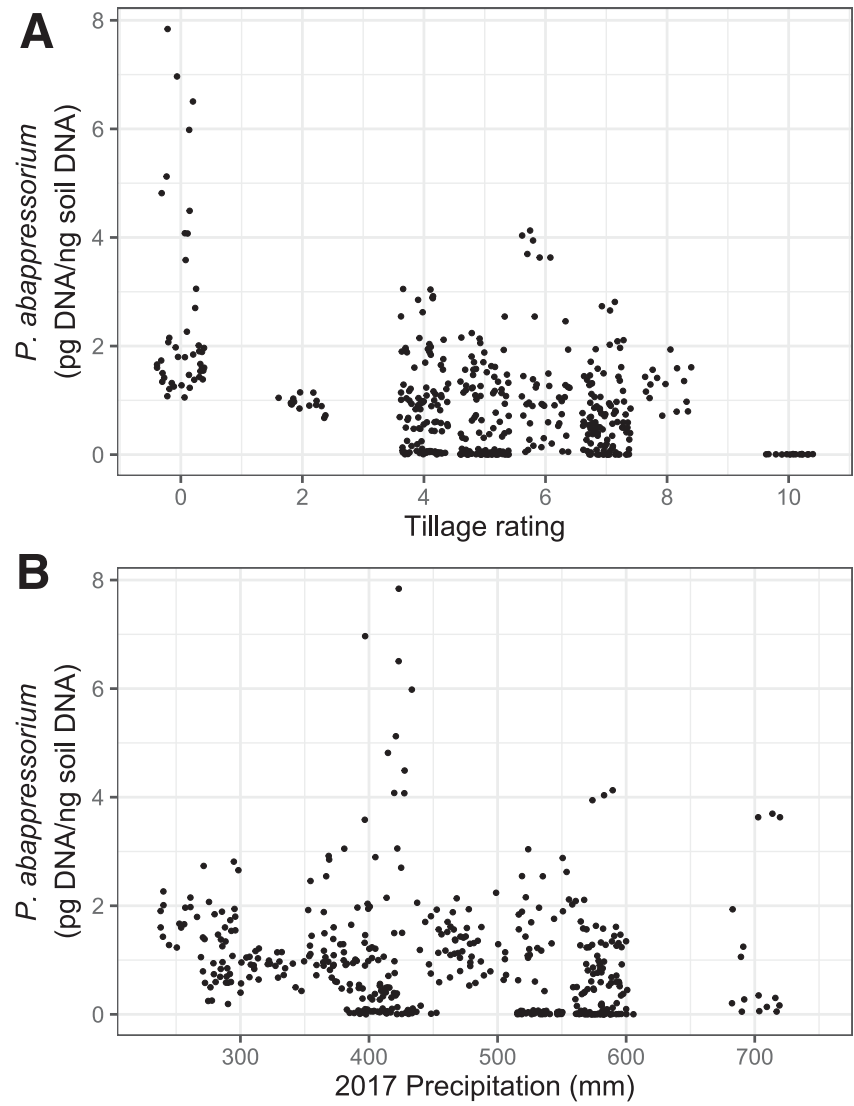

Fig. 9. Scatter plots of qPCR quantification of Pythium abappressorium pg of DNA/ng of soil DNA collected from commercial winter wheat fields in Umatilla County, OR under different tillage and precipitation regimes. A, Tillage scale: $0=$ no tillage, and $10=$ conventional inversion tillage. B, Different precipitation. Each point represents one technical replicate. 
many cropping cycles for changes in microbial communities, including pathogens, to be realized. Reciprocal effects between abiotic and biotic factors may further prolong the changes that occur after a transition to no-till.

The results of this study have a scope of inference limited to commercial winter wheat fields of Umatilla County in a regionally typical wheat-fallow rotation. Our results suggest that potential for increased soilborne disease should not be a major limiting factor for the adoption of no-till technology in the dryland Pacific Northwest. We hypothesize the benefits of adopting no-till technology outweigh the potential risk of increased soilborne disease. And negative pathogen-related effects of a transition from conventional tillage to no-tillage, including increased substrate for residue-borne and soilborne pathogens, are realized immediately. However, positive pathogenic-related effects, including the buildup of competitive and suppressive beneficial soilborne bacteria and fungi, may take many cropping cycles to take effect.

Microbiota management with farming practices could be a key next step to understanding the resilience of a total farming operation. Next-generation technology and a microbiome approach will allow us to utilize beneficial soil microbial communities to support sustainable agriculture and protect farm profitability. Research should support the no-till management strategy so that growers are equipped with data-driven decision-making tools for crop production. This project serves as a first step as we work to provide growers with a set of innovative disease management tools and decision-making strategies that can accommodate no-till and conventional production strategies. Transitioning from conventional tillage to no-tillage requires a large investment of equipment. Farmers need data to support this investment, so they may feel confident in making significant changes to cultural management.
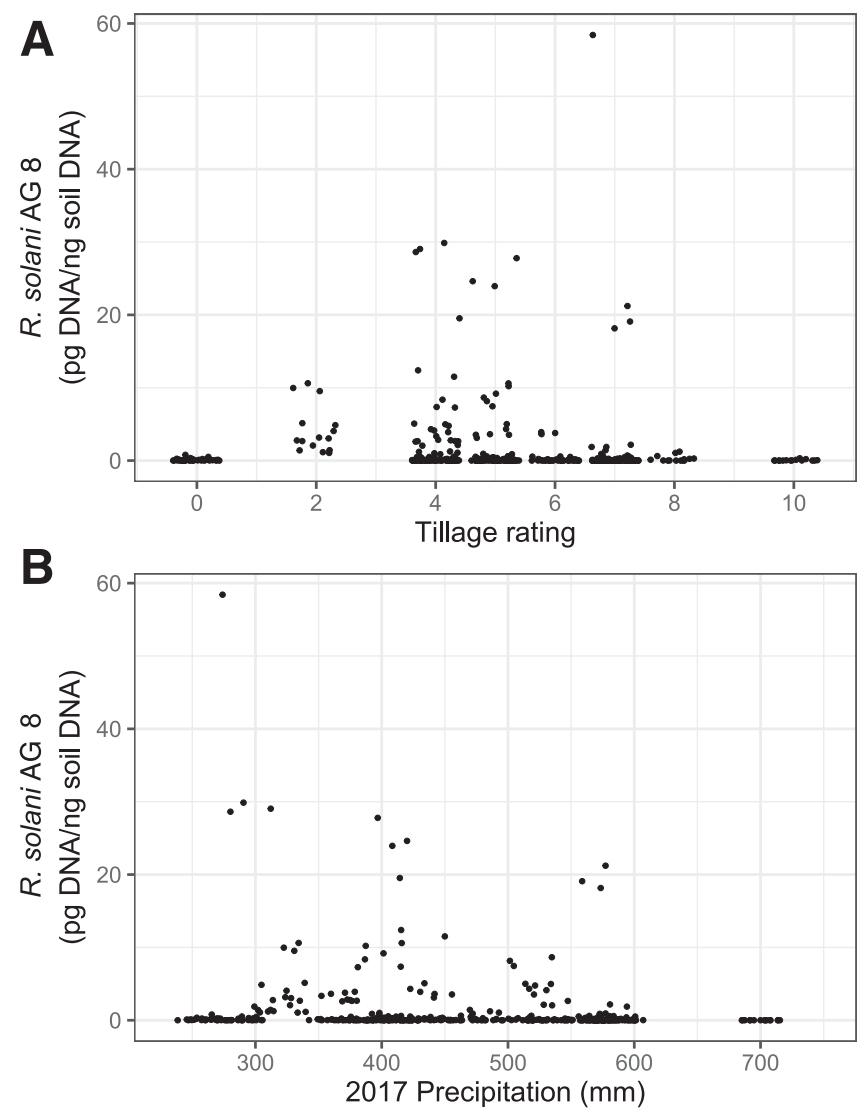

Fig. 10. Scatter plots of qPCR quantification of Rhizoctonia solani AG $8 \mathrm{pg}$ of DNA/ng of soil DNA collected from commercial winter wheat fields in Umatilla County, OR, under different tillage and precipitation regimes. A, Tillage scale: $0=$ no tillage, and $10=$ conventional inversion tillage. B, Different precipitation. Each point represents one technical replicate.

\section{Acknowledgments}

We thank the Oregon Wheat Growers League and the wheat farmers who allowed us to sample their fields. Special thanks are due to Robert Cating for assistance with the dilution plating method and to Cuiling Gao for assistance with soil DNA extraction.

\section{Literature Cited}

Anderson, N. A. 1982. The genetics and pathology of Rhizoctonia solani. Annu. Rev. Phytopathol. 20:329-347.

Bates, D., Maechler, M., Bolker, B., and Walker, S. 2014. lme4: Linear mixedeffects models using Eigen and S4. R package version. 1. https://cran.rproject.org/web/packages/lme4/lme4.pdf.

Bockus, W. W., Bowden, R. L., Hunger, R. M., Morrill, W. L., Murray, T. D., and Smiley, R. W., eds. 2010. Compendium of Wheat Diseases and Pests, 3rd Ed. American Phytopathological Society, St. Paul, MN.

Bockus, W. W., and Shroyer, J. P. 1998. The impact of reduced tillage on soilborne plant pathogens. Annu. Rev. Phytopathol. 36:485-500.

Chamswarng, C., and Cook, R. J. 1985. Identification and comparative pathogenicity of Pythium species from wheat roots and wheat-field soils in the Pacific Northwest. Phytopathology 75:821-827.

Conner, R. J., Lindwall, C. W., and Atkinson, T. G. 1987. Influence of minimum tillage on severity of common root rot in wheat. Can. J. Plant Pathol. 9:56-58.

Cook, R. J. 2001. Management of wheat and barley root diseases in modern farming systems. Australas. Plant Pathol. 30:119-126.

Cook, R. J. 2010. Fusarium root, crown, and foot rots and associated seedling disease. Pages 37-39 in: Compendium of Wheat Diseases and Pests, 3rd Ed. American Phytopathological Society, St. Paul, MN.

Cook, R. J., Schillinger, W. F., and Christensen, N. W. 2002. Rhizoctonia root rot and take-all of wheat in diverse direct-seed spring cropping systems. Can. J. Plant Pathol. 24:349-358.

Cook, R. J., Sitton, J. W., and Waldher, J. T. 1980. Evidence for Pythium as a pathogen of direct-drilled wheat in the Pacific Northwest. Plant Dis. 64: 102-103.

Dada, T. 2017. Epidemiology of wheat Rhizoctonia. Int. J. Sci. Res. Pub. 7:463.

De Boer, R. F., and Kollmorgen, J. F. 1988. Effects of cultivation and stubble retention on soil and stubble-born pathogens of wheat in Victoria-An overview. Plant Prot. Q. 3:3-4.

Dweba, C. C., Figlan, S., Shimelis, H. A., Motaung, T. E., Sydenham, S., Mwadzingeni, L., and Tsilo, T. J. 2017. Fusarium head blight of wheat: Pathogenesis and control strategies. Crop Prot. 91:114-122.

González, D., Cubeta, M. A., and Vilgalys, R. 2006. Phylogenetic utility of indels within ribosomal DNA and $\beta$-tubulin sequences from fungi in the Rhizoctonia solani species complex. Mol. Phylogenet. Evol. 40:459-470.

Hagerty, C. H., Ficaks, K. C., and Wysocki, D. 2019. Agronomic Zones of the Dryland Pacific Northwest. PNW 354. Oregon State University, Corvallis, OR.

Higginbotham, R. W., Paulitz, T. C., and Kidwell, K. K. 2004. Virulence of Pythium species isolated from wheat fields in eastern Washington. Plant Dis. 88:1021-1026.

Hofgaard, I. S., Seehusen, T., Aamot, H. U., Riley, H., Razzaghian, J., Le, V. H., Hjelkrem, A. G., Dill-Macky, R., and Brodal, G. 2016. Inoculum potential of Fusarium spp. relates to tillage and straw management in Norwegian fields of spring oats. Front. Microbiol. 7:556.

Huntington, J., Hegewisch, K., Daudert, B., Morton, C., Abatzoglou, J., McEvoy, D., et al. 2017. Climate Engine: Cloud Computing of Climate and Remote Sensing Data for Advanced Natural Resource Monitoring and Process Understanding. American Meteorological Society. http://climateengine.org/.

Ingram, D. M., and Cook, R. J. 1990. Pathogenicity of four Pythium species to wheat, barley, peas and lentils. Plant Pathol. 39:110-117.

Kazan, K., and Gardiner, D. M. 2018. Fusarium crown rot caused by Fusarium pseudograminearum in cereal crops: Recent progress and future prospects. Mol. Plant Pathol. 19:1547-1562.

Komada, H. 1975. Development of a selective medium for quantitative isolation of Fusarium oxysporum from natural soil. Rev. Plant Prot. Res. 8:114-124.

Lamichhane, J. R., Dürr, C., Schwanck, A. A., Robin, M. H., Sarthou, J. P., Cellier, V., Messéan, A., and Aubertot, J. N. 2017. Integrated management of dampingoff diseases: A review. Agron. Sustain. Dev. 37:10.

Larkin, R. P. 2015. Soil health paradigms and implications for disease management. Annu. Rev. Phytopathol. 53:199-221.

Lawn, D. A., and Sayre, K. D. 1989. Effects of crop rotation tillage and straw management on common root rot of wheat. Phytopathology 79:1142.

Lori, G. A., Sisterna, M. N., Sarandón, S. J., Rizzo, I., and Chidichimo, H. 2009. Fusarium head blight in wheat: Impact of tillage and other agronomic practices under natural infection. Crop Prot. 28:495-502.

MacNish, G. C. 1985. Methods of reducing Rhizoctonia patch of cereals in Western Australia. Plant Pathol. 34:175-181.

Maiorano, A., Blandino, M., Reyneri, A., and Vanara, F. 2008. Effects of maize residues on the Fusarium spp. infection and deoxynivalenol (DON) contamination of wheat grain. Crop Prot. 27:182-188.

Martin, F. N., and Loper, J. E. 1999. Soilborne plant diseases caused by Pythium spp.: Ecology, epidemiology, and prospects for biological control. Crit. Rev. Plant Sci. 18:111-181. 
Mazzola, M., Wong, O. T., and Cook, R. J. 1996. Virulence of Rhizoctonia oryzae and $R$. solani AG- 8 on wheat and detection of $R$. oryzae in plant tissue by PCR. Phytopathology 86:354-360.

Mihail, J. D., and Singleton, L. L. 1992. Methods for Research on Soilborne Phytopathogenic Fungi. C. M. Rush, ed. American Phytopathological Society, St. Paul, MN.

Moya-Elizondo, E. A. 2013. Fusarium crown rot disease: Biology, interactions, management and function as a possible sensor of global climate change. Cien. Inv. Agr. 40:235-252.

Munger, H., Vanasse, A., Rioux, S., and Légère, A. 2014. Bread wheat performance, Fusarium head blight incidence and weed infestation response to low-input conservation tillage systems in eastern Canada. Can. J. Plant Sci. 94:193-201.

Okubara, P. A., Schroeder, K. L., Abatzoglou, J. T., and Paulitz, T. C. 2014. Agroecological factors correlated to soil DNA concentrations of Rhizoctonia in dryland wheat production zones of Washington state, USA. Phytopathology 104:683-691.

Okubara, P. A., Schroeder, K. L., and Paulitz, T. C. 2005. Real-time polymerase chain reaction: Applications to studies on soilborne pathogens. Can. J. Plant Pathol. 27:300-313.

Okubara, P. A., Schroeder, K. L., and Paulitz, T. C. 2008. Identification and quantification of Rhizoctonia solani and $R$. oryzae using real-time polymerase chain reaction. Phytopathology 98:837-847.

Pankhurst, C. E., McDonald, H. J., and Hawke, B. G. 1995. Influence of tillage and crop rotation on the epidemiology of Pythium infections of wheat in a redbrown earth of South Australia. Soil Bio. Biochem. 27:1065-1073.

Paulitz, T. C. 2006. Low input no-till cereal production in the Pacific Northwest of the U.S.: The challenges of root diseases. Eur. J. Plant Pathol. 115:271-281.

Paulitz, T. C., and Schroeder, K. L. 2005. A new method for the quantification of Rhizoctonia solani and R. oryzae from soil. Plant Dis. 89:767-772.

Paulitz, T. C., Smiley, R. W., and Cook, R. J. 2002. Insights into the prevalence and management of soilborne cereal pathogens under direct seeding in the Pacific Northwest, U.S.A. Can. J. Plant Pathol. 24:416-428.

Pittelkow, C. M., Linquist, B. A., Lundy, M. E., Liang, X., van Groenigen, K. J., Lee, J., van Gestel, N., Six, J., Venterea, R. T., and Kessel, C. 2015. When does no-till yield more? A global meta-analysis. Field Crops Res. 183:156-168.

Poole, G. J., Smiley, R. W., Walker, C., Huggins, D., Rupp, R., Abatzoglou, J., Garland-Campbell, K., and Paulitz, T. C. 2013. Effect of climate on the distribution of Fusarium spp. causing crown rot of wheat in the Pacific Northwest of the United States. Phytopathology 103:1130-1140.

Pumphrey, F. V., Wilkins, D. E., Hane, D. C., and Smiley, R. W. 1987. Influence of tillage and nitrogen fertilizer on Rhizoctonia root rot (bare patch) of winter wheat. Plant Dis. 71:125.

Roberts, F. A., and Sivasithamparam, K. 1986. Identity and pathogenicity of Rhizoctonia spp. associated with bare patch disease of cereals at a field site in Western Australia. Nether. J. Plant Pathol. 92:185-195.

Roget, D. K. 1995. Decline in root rot (Rhizoctonia solani AG-8) in wheat in a tillage and rotation experiment at Avon, South Australia. Aust. J. Exp. Agric. 35:1009-1013

Rovira, A. D. 1986. Influence of crop rotation and tillage on Rhizoctonia bare patch of wheat. Phytopathology 76:669-673.

Salas, B., and Stack, R. W. 1988. Effect of cultural practices on common root rot of spring wheat. Phytopathology 78:1598.

Schroeder, K. L., Okubara, P. A., Tambong, J. T., Lévesque, C. A., and Paulitz, T. C. 2006. Identification and quantification of pathogenic Pythium spp. from soils in eastern Washington using real-time polymerase chain reaction. Phytopathology 96:637-647.

Smiley, R. W., Collins, H. P., and Rasmussen, P. E. 1996. Diseases of wheat in long-term agronomic experiments at Pendleton, Oregon. Plant Dis. 80: 813-820.

Smiley, R. W., Gourlie, J. A., Easley, S. A., Patterson, L. M., and Whittaker, R. G. 2005a. Crop damage estimates for crown rot of wheat and barley in the Pacific Northwest. Plant Dis. 89:595-604.

Smiley, R. W., and Patterson, L. M. 1996. Pathogenic fungi associated with Fusarium foot rot of winter wheat in the semiarid Pacific Northwest. Plant Dis. 80:944-949.

Smiley, R. W., Paulitz, T., and Marshall, J. 2012. Controlling Root and Crown Diseases of Small Grain Cereals. Oregon State University, Corvallis, OR.

Smiley, R. W., Siemens, M., Gohlke, T., and Poore, J. 2005b. Small grain acreage and management trends for eastern Oregon and Washington. Pages 30-50 in: 2005 Dryland Agricultural Research Annual Report. SR 1061. D. A. Long, S. E. Petrie, and P. M. Frank, eds. Oregon State University, Corvallis, OR.

Smiley, R. W., and Uddin, W. 1993. Influence of soil temperature on Rhizoctonia root rot ( $R$. solani AG-8 and $R$. oryzae) of winter wheat. Phytopathology 83: 777-785.

Smiley, R. W., and Yan, H. 2009. Variability of Fusarium crown rot tolerances among cultivars of spring and winter wheat. Plant Dis. 93:954-961.

Steinkellner, S., and Langer, I. 2004. Impact of tillage on the incidence of Fusarium spp. in soil. Plant Soil 267:13-22.

Tewoldemedhin, Y. T., Lamprecht, S. C., McLeod, A., and Mazzola, M. 2006. Characterization of Rhizoctonia spp. recovered from crop plants used in rotational cropping systems in the Western Cape province of South Africa. Plant Dis. 90:1399-1406.

Tinline, R. D., and Spurr, D. T. 1991. Agronomic practices and common root rot in spring wheat: Effect of tillage on disease and inoculum density of Cochliobolus sativus in soil. Can. J. Plant Pathol. 13:258-266.

USDA National Agriculture Statistics Service. 2017. USDA/NASS QuickStats Wheat Value 2017. https://quickstats.nass.usda.gov/results/B05C556C-D51C3450-8A40-2C2D6FEC7723.

Wildermuth, G. B., Thomas, G. A., Radford, B. J., McNamara, R. B., and Kelly, A. 1997. Crown rot and common root rot in wheat grown under different tillage and stubble treatments in southern Queensland, Australia. Soil Tillage Res. 44:211-224.

Windels, C. E., and Wiersma, V. 1989. Infection differences of Bipolaris and Fusarium in subcrown internodes of barley and wheat grown in no-till and moldboard plow systems. Phytopathology 79:1006.

Wong, D. H., Barbetti, M. J., and Sivasithamparam, K. 1984. Effects of soil temperature and moisture on the pathogenicity of fungi associated with root rot of subterranean clover. Aust. J. Agric. Res. 35:675-684

Woodhall, J. W., Adams, I. P., Peters, J. C., Harper, G., and Boonham, N. 2013. A new quantitative real-time PCR assay for Rhizoctonia solani AG3-PT and the detection of AGs of Rhizoctonia solani associated with potato in soil and tuber samples in Great Britain. Eur. J. Plant Pathol. 136:273-280.

Yin, C., Mueth, N., Hulbert, S., Schlatter, D., Paulitz, T. C., Schroeder, K., Prescott, A., and Dhingra, A. 2017. Bacterial communities on wheat grown under long-term conventional tillage and no-till in the Pacific Northwest of the United States. Phytobiomes J. 1:83-90.

Yorgey, G., and Kruger, C., eds. 2017. Advances in Dryland Farming in the Inland Pacific Northwest. Washington State University, Pullman, WA. https:// extension.wsu.edu/publications/pubs/em108/ 